\title{
Antibiotic sensitivities of urinary pathogens, 1971-8
}

\author{
RN GRUNEBERG \\ From University College Hospital, London WC1E 6AU, UK
}

SUMMARY The sensitivities of urinary pathogens from general practice and from hospital to a range of antimicrobial drugs have been recorded for the period 1971-8. There have been changes in the proportions of the different bacterial species and in their sensitivities to antibiotics. In particular, the position of ampicillin/amoxycillin and cephalosporins has deteriorated, partly because more resistant species have somewhat increased in prevalence and partly because the usually sensitive species, such as Escherichia coli, have become more resistant. Over the period 1971-8 the sensitivity of urinary pathogens, whether in general practice or in hospital, to co-trimoxazole and to trimethoprim has been maintained at a high level.

The organisms causing urinary tract infection (UTI) vary from place to place and from time to time, and so do their sensitivities to antibiotics. Presumably some of the variation reflects different antibiotic prescribing habits. Whatever the reasons for the differences, they determine the likely outcome of antibiotic treatment. There are, therefore, two main reasons for collecting the results of antibiotic sensitivity tests on urinary pathogens: to collect ecological information, and to predict the outcome of treatment of UTI when chemotherapy must be started before laboratory results are available.

\section{Methods}

For the last eight years, all urinary pathogens isolated from patients in the outlying hospitals in the University College Hospital group (hospital strains) and all those from samples sent to the hospital laboratory by general practitioners (general practice strains) have been examined. The numbers and types of organisms seen in 1971, 1972, and

Received for publication 25 February 1980 alternate years thereafter are shown in Tables 1 and 2. The proportions of all urinary pathogens from each source that were fully sensitive to a range of drugs in those years are presented in Tables 3 and 4. Sensitivity tests were performed using Stokes'1 technique.

\section{Results and discussion}

For a variety of reasons the mix of pathogens causing UTI in hospital is different from that in general practice. This alone will cause differences in the effectiveness of various drugs in the two situations. Two examples are the much greater prevalence of the inherently ampicillin-resistant Klebsiella spp. in hospital UTI, and the more frequent occurrence of the nalidixic acid-resistant staphylococci among GP urinary isolates than among hospital strains. Similarly, if the mix of bacterial pathogens causing UTI changes with time, there may be corresponding changes in the sensitivities of the bacterial flora.

In general, as can be seen from Tables 1 and 2, there has been a fairly stable relationship between the bacterial species causing UTI, whether in general

Table 1 Organisms causing general practice UT1, i971-8

\begin{tabular}{|c|c|c|c|c|c|c|c|c|c|c|}
\hline \multirow[t]{2}{*}{ Organism } & \multicolumn{2}{|l|}{1971} & \multicolumn{2}{|l|}{1972} & \multicolumn{2}{|l|}{1974} & \multicolumn{2}{|c|}{1976} & \multicolumn{2}{|c|}{1978} \\
\hline & No. & $\%$ & No. & $\%$ & No. & $\%$ & No. & $\%$ & No. & $\%$ \\
\hline $\begin{array}{l}\text { Esch. coli } \\
\text { Proteus mirabilis } \\
\text { Klebsiella-Enterobacter spp. } \\
\text { Enterococci } \\
\text { Staphylococci } \\
\text { Others }\end{array}$ & $\begin{array}{r}340 \\
40 \\
10 \\
10 \\
22 \\
11\end{array}$ & $\begin{array}{r}78 \cdot 5 \\
9 \cdot 2 \\
2 \cdot 3 \\
2 \cdot 3 \\
5 \cdot 1 \\
2 \cdot 6\end{array}$ & $\begin{array}{r}308 \\
42 \\
14 \\
16 \\
24 \\
14\end{array}$ & $\begin{array}{r}73 \cdot 6 \\
10 \cdot 0 \\
3 \cdot 3 \\
3 \cdot 8 \\
5 \cdot 7 \\
3 \cdot 6\end{array}$ & $\begin{array}{r}451 \\
38 \\
27 \\
17 \\
41 \\
11\end{array}$ & $\begin{array}{r}77 \cdot 1 \\
6.5 \\
4.6 \\
2.9 \\
7.0 \\
1.9\end{array}$ & $\begin{array}{r}502 \\
38 \\
28 \\
27 \\
67 \\
19\end{array}$ & $\begin{array}{r}73 \cdot 6 \\
5 \cdot 6 \\
4 \cdot 1 \\
4 \cdot 0 \\
9 \cdot 8 \\
2 \cdot 9\end{array}$ & $\begin{array}{r}454 \\
30 \\
27 \\
12 \\
59 \\
24\end{array}$ & $\begin{array}{r}74 \cdot 9 \\
4 \cdot 9 \\
4 \cdot 5 \\
2 \cdot 0 \\
9 \cdot 7 \\
4 \cdot 0\end{array}$ \\
\hline Total & 433 & $100 \cdot 0$ & 418 & $100 \cdot 0$ & 585 & $100 \cdot 0$ & 681 & $100 \cdot 0$ & 606 & $100 \cdot 0$ \\
\hline
\end{tabular}


Table 2 Organisms causing UTI in hospital, 1971-8

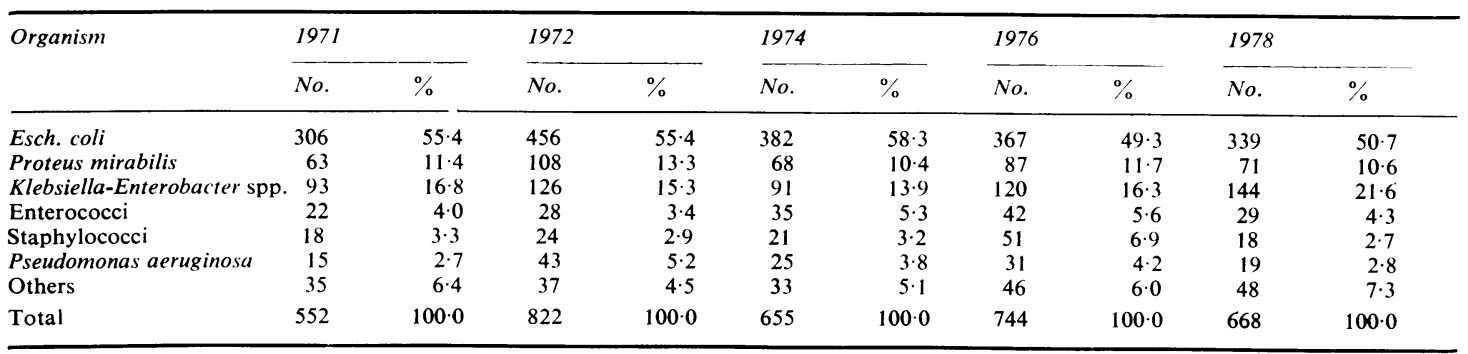

Table 3 Proportions of all urinary pathogens fully sensitive to various antimicrobials in general practice, 1971-8

\begin{tabular}{|c|c|c|c|c|c|c|}
\hline \multirow{3}{*}{$\begin{array}{l}\text { Drug } \\
\text { Ampicillin/Amoxycillin }\end{array}$} & \multicolumn{6}{|c|}{ Percentage of strains fully sensitive (ranking) } \\
\hline & $\begin{array}{l}1971 \\
n=433\end{array}$ & $\begin{array}{l}1972 \\
n=418\end{array}$ & $\begin{array}{l}l 974 \\
n=585\end{array}$ & $\begin{array}{l}1976 \\
n=681\end{array}$ & \multicolumn{2}{|c|}{$\begin{array}{l}1978 \\
n=606\end{array}$} \\
\hline & $88 \cdot 2 \quad(4)$ & $84 \cdot 4 \quad(6)$ & $81 \cdot 2 \quad(7)$ & $80 \cdot 9 \quad(7)$ & $79 \cdot 4$ & (7) \\
\hline Cephalosporin & $87 \cdot 5 \quad(5)$ & $85 \cdot 1 \quad(4)$ & $83 \cdot 1 \quad(6)$ & $81 \cdot 6 \quad(6)$ & $84 \cdot 5$ & (6) \\
\hline Colistin sulphamethate & $85 \cdot 0 \quad(7)$ & $82 \cdot 3 \quad(7)$ & $87 \cdot 9 \quad(4)$ & $85 \cdot 0 \quad(4)$ & $90 \cdot 3$ & (4) \\
\hline Co-trimoxazole & $96.6 \quad(1)$ & $96 \cdot 4 \quad(1)$ & $93 \cdot 2 \quad(1)$ & $96 \cdot 7$ & $97 \cdot 0$ & (1) \\
\hline Nitrofurantoin & $85 \cdot 6 \quad(6)$ & $85 \cdot 1 \quad(4)$ & $88 \cdot 4$ & $90 \cdot 1$ & $90 \cdot 6$ & (3) \\
\hline Sulphonamide & $76.4 \quad(8)$ & $73 \cdot 1 \quad(8)$ & $73 \cdot 7$ & $78 \cdot 1$ & $73 \cdot 6$ & (9) \\
\hline Tetracycline & $72 \cdot 5 \quad(9)$ & $69 \cdot 6 \quad(9)$ & $73 \cdot 6$ & $74 \cdot 5$ & $75 \cdot 7$ & (8) \\
\hline Trimethoprim & $94 \cdot 0 \quad(2)$ & $94.4 \quad$ (2) & $89 \cdot 5 \quad$ (2) & $92 \cdot 7 \quad$ (2) & 90.9 & (2) \\
\hline
\end{tabular}

Table 4 Proportions of all urinary pathogens fully sensitive to various antimicrobials in hospital, 1971-8

\begin{tabular}{|c|c|c|c|c|c|}
\hline \multirow[t]{2}{*}{ Drug } & \multicolumn{5}{|c|}{ Percentage of strains fully sensitive (ranking) } \\
\hline & $\begin{array}{l}1971 \\
n=552\end{array}$ & $\begin{array}{l}1972 \\
n=882\end{array}$ & $\begin{array}{l}1974 \\
n=655\end{array}$ & $\begin{array}{l}1976 \\
n=744\end{array}$ & $\begin{array}{l}1978 \\
n=668\end{array}$ \\
\hline Ampicillin/Amoxycillin & $66 \cdot 1$ & $64 \cdot 2$ & $61 \cdot 2 \quad(7)$ & $53 \cdot 7 \quad(9)$ & $51 \cdot 2 \quad(9)$ \\
\hline Cephalosporin & $69 \cdot 9$ & $68 \cdot 1$ & $63 \cdot 2 \quad(6)$ & $57 \cdot 2 \quad(7)$ & $58 \cdot 2 \quad(8)$ \\
\hline Colistin sulphamethate & $76 \cdot 8$ & $78 \cdot 6$ & $78 \cdot 0$ & $74 \cdot 7$ & $80 \cdot 4 \quad(3)$ \\
\hline Co-trimoxazole & 839 & $81 \cdot 7$ & $76 \cdot 2$ & $81 \cdot 2 \quad(1)$ & $82 \cdot 5 \quad(2)$ \\
\hline Nalidixic acid & $84 \cdot 8$ & $82 \cdot 6$ & $80 \cdot 6$ & $75 \cdot 3$ & $85 \cdot 5 \quad(1)$ \\
\hline Nitrofurantoin & $70 \cdot 3$ & $71 \cdot 5$ & $72 \cdot 7$ & $73 \cdot 2$ & $74 \cdot 4 \quad$ (4) \\
\hline Sulphonamide & $61 \cdot 9$ & $62 \cdot 2$ & $57 \cdot 4$ & 58.9 & $58 \cdot 5 \quad(7)$ \\
\hline Tetracycline & $55 \cdot 8$ & $56 \cdot 1$ & $48 \cdot 6$ & $54 \cdot 0$ & $59 \cdot 3 \quad(6)$ \\
\hline Trimethoprim & $79 \cdot 9$ & $80 \cdot 7 \quad$ (3) & $71 \cdot 5 \quad(5)$ & $76 \cdot 4 \quad(2)$ & $74 \cdot 1 \quad$ (5) \\
\hline
\end{tabular}

practice or in hospital. In general practice, the main changes have been a reduction of Proteus mirabilis (which is resistant, or moderately resistant, to nitrofurantoin and is resistant to colistin and the tetracyclines) and an increase in staphylococci (which are resistant to nalidixic acid) in the last eight years. It is not known why staphylococcal isolates have increased in urinary material but the explanation does not lie in increased laboratory awareness of the possible pathogenic role of micrococci. In hospital there has been an increase in Klebsiella-Enterobacter spp. (which are inherently ampicillin-resistant) during the period of the study.

The general practice strains (Table 3 ) are much more antibiotic-sensitive than the hospital strains (Table 4). The main changes in general practice (Table 3) have been the steady decline in ampicillin/ amoxycillin sensitivity $(88.2 \%$ sensitive in 1971 and
$79.4 \%$ in 1978) and some decline in nalidixic acid sensitivity, reflecting the increased number of staphylococci isolated over the review period. The sensitivity of GP strains to trimethoprim and to co-trimoxazole has been maintained throughout the period, co-trimoxazole being the 'best guess' for unguided chemotherapy in every one of the eight years from 1971 to 1978 .

Among the hospital strains (Table 4), ampicillin/ amoxycillin sensitivity has declined from $66.1 \%$ sensitive in 1971 to $51.2 \%$ sensitive in 1978 , and cephalosporin from $69.9 \%$ to $58.2 \%$ between 1971 and 1978. Despite some reduction in trimethoprim sensitivity in the review period, the sensitivity of hospital strains to co-trimoxazole has hardly changed, and this drug has been first, second, or third 'best guess' in every one of the eight years reviewed. 
In an attempt to remove the distorting effect of varying proportions of different bacterial species, Tables 5 and 6 show an analysis of one organism only, the usually antibiotic-sensitive Esch. coli, which is the commonest pathogen causing UTI, whether in general practice or in hospital. Examination of Table 5 shows that general practice Esch. coli from UTI has on the whole become less sensitive to ampicillin/amoxycillin and cephalosporins and perhaps sulphonamides but not significantly so to other drugs, including trimethoprim and co-trimoxazole. Similar examination of Esch. coli from hospital UTI (Table 6) again shows increased resistance to ampicillin/amoxycillin, cephalosporins, and sulphonamides, but not to other drugs, including trimethoprim and co-trimoxazole. Thus it can be seen that the declining position of ampicillin/ amoxycillin and the cephalosporins is due partly to an increased prevalence of more resistant bacterial species, and partly to increasing resistance within bacterial species.

A report of the first four years' findings of this study ${ }^{2}$ indicated that some of the antibiotic choices implied in the observations were more apparent than real, because trimethoprim was at the time not available independently of sulphonamide, and because colistin has to be given parenterally, which is often not convenient. Trimethoprim is now available for use on its own. A choice made solely on the basis of breadth of antimicrobial spectrum in general practice in 1978 would rank the drugs in decreasing order of preference as follows: cotrimoxazole, trimethoprim, nitrofurantoin, nalidixic acid, a cephalosporin, amoxycillin, a tetracycline, a sulphonamide. Clearly, the choice of treatment would not be made solely on this basis, since considerations such as frequency of administration, nature and frequency of side effects, acceptability to the patient, ecological effects, and cost must be taken into account. This ranking in 1978 is almost identical with that which applied in 1974.

In hospital, parenteral therapy is more feasible than in general practice, although oral treatment is preferred. The choice of treatment, if made solely on the basis of breadth of spectrum in 1978, would rank the drugs in decreasing preference thus: nalidixic acid, co-trimoxazole, colistin, nitrofurantoin, trimethoprim, a tetracycline, a sulphonamide, a cephalosporin, amoxycillin. There are no very striking changes at the top of this list compared with the situation in 1974. Sulphonamides and tetracyclines have been moved from the bottom of the list by the arrival there of amoxycillin and the cephalosporins.

There has been only a very slight decline in the sensitivity of urinary pathogens, whether in general practice or in hospital, to both trimethoprim and sulphonamides in the period 1971-8. This has not had any deleterious effect on the usefulness of cotrimoxazole in either environment. How sensitivities of urinary isolates will be affected by the marketing in the United Kingdom in 1979 of trimethoprim on its own remains to be seen.

It can be seen from the results here presented that, despite some slow deterioration, the generality of urinary pathogens remains sensitive to many antibiotics. Antibiotic resistance is rarely a bar to effective treatment. The time may, however, have come to start testing newer products such as mecillinam to assess their usefulness.

I am grateful to my colleagues in the microbiology

Table 5 Percentage of urinary Esch. coli from hospital practice 1971-8 fully sensitive to various antimicrobials

\begin{tabular}{|c|c|c|c|c|c|c|c|c|c|c|}
\hline Year & $\begin{array}{l}\text { No. of } \\
\text { strains }\end{array}$ & $\begin{array}{l}\text { Ampicillin/ } \\
\text { Amoxycillin }\end{array}$ & $\begin{array}{l}\text { Cephalo- } \\
\text { sporin }\end{array}$ & $\begin{array}{l}\text { Colistin } \\
\text { sulphame- } \\
\text { thate }\end{array}$ & $\begin{array}{l}\text { Co-trimoxa- } \\
\text { zole }\end{array}$ & $\begin{array}{l}\text { Nalidixic } \\
\text { acid }\end{array}$ & $\begin{array}{l}\text { Nitro- } \\
\text { furantoin }\end{array}$ & $\begin{array}{l}\text { Sulphon- } \\
\text { amide }\end{array}$ & $\begin{array}{l}\text { Tetra- } \\
\text { cycline }\end{array}$ & $\begin{array}{l}\text { Tri- } \\
\text { methoprim }\end{array}$ \\
\hline $\begin{array}{l}1971 \\
1972 \\
1974 \\
1976 \\
1978\end{array}$ & $\begin{array}{l}340 \\
308 \\
451 \\
502 \\
454\end{array}$ & $\begin{array}{l}91 \cdot 4 \\
88 \cdot 9 \\
85 \cdot 6 \\
83 \cdot 4 \\
86 \cdot 3\end{array}$ & $\begin{array}{l}91 \cdot 2 \\
88 \cdot 7 \\
85 \cdot 6 \\
84 \cdot 1 \\
87 \cdot 0\end{array}$ & $\begin{array}{c}100 \\
99 \cdot 6 \\
100 \\
100 \\
100\end{array}$ & $\begin{array}{l}99 \cdot 2 \\
99 \cdot 6 \\
98 \cdot 9 \\
98 \cdot 4 \\
98 \cdot 2\end{array}$ & $\begin{array}{l}99 \cdot 1 \\
99 \cdot 0 \\
97 \cdot 8 \\
98 \cdot 4 \\
99 \cdot 3\end{array}$ & $\begin{array}{l}97 \cdot 6 \\
97 \cdot 0 \\
98 \cdot 3 \\
97 \cdot 7 \\
98 \cdot 2\end{array}$ & $\begin{array}{l}77 \cdot 3 \\
75 \cdot 3 \\
74 \cdot 3 \\
79 \cdot 4 \\
72 \cdot 5\end{array}$ & $\begin{array}{l}81 \cdot 2 \\
81 \cdot 2 \\
80 \cdot 0 \\
80 \cdot 5 \\
81 \cdot 5\end{array}$ & $\begin{array}{l}98.5 \\
99.6 \\
97.9 \\
97.4 \\
96.5\end{array}$ \\
\hline
\end{tabular}

Table 6 Percentage of urinary Esch. coli from hospital practice 1971-8 fully sensitive to various antimicrobials

\begin{tabular}{|c|c|c|c|c|c|c|c|c|c|c|}
\hline Year & $\begin{array}{l}\text { No. of } \\
\text { strains }\end{array}$ & $\begin{array}{l}\text { Ampicillin/ } \\
\text { Amoxycillin }\end{array}$ & $\begin{array}{l}\text { Cephalo- } \\
\text { sporin }\end{array}$ & $\begin{array}{l}\text { Colistin } \\
\text { sulphame- } \\
\text { thate }\end{array}$ & $\begin{array}{l}\text { Co-trimoxa- } \\
\text { zole }\end{array}$ & $\begin{array}{l}\text { Nalidixic } \\
\text { acid }\end{array}$ & $\begin{array}{l}\text { Nitro- } \\
\text { furantoin }\end{array}$ & $\begin{array}{l}\text { Sulphon- } \\
\text { amide }\end{array}$ & $\begin{array}{l}\text { Tetra- } \\
\text { cycline }\end{array}$ & $\begin{array}{l}\text { Tri- } \\
\text { methoprim }\end{array}$ \\
\hline $\begin{array}{l}1971 \\
1972 \\
1974 \\
1976 \\
1978\end{array}$ & $\begin{array}{l}306 \\
456 \\
382 \\
367 \\
339\end{array}$ & $\begin{array}{l}84 \cdot 4 \\
81 \cdot 3 \\
74 \cdot 3 \\
68 \cdot 3 \\
73 \cdot 2\end{array}$ & $\begin{array}{l}86.6 \\
81.9 \\
74 \cdot 3 \\
67 \cdot 8 \\
73.5\end{array}$ & $\begin{array}{c}100 \\
100 \\
100 \\
99 \cdot 8 \\
100\end{array}$ & $\begin{array}{l}97 \cdot 0 \\
95 \cdot 2 \\
93 \cdot 4 \\
96 \cdot 1 \\
95 \cdot 9\end{array}$ & $\begin{array}{l}98 \cdot 1 \\
98 \cdot 4 \\
97 \cdot 1 \\
97 \cdot 1 \\
97 \cdot 9\end{array}$ & $\begin{array}{l}95 \cdot 7 \\
97 \cdot 7 \\
97 \cdot 8 \\
97 \cdot 1 \\
97 \cdot 1\end{array}$ & $\begin{array}{l}75 \cdot 3 \\
68 \cdot 9 \\
66 \cdot 4 \\
64 \cdot 6 \\
69 \cdot 6\end{array}$ & $\begin{array}{l}75 \cdot 8 \\
78 \cdot 3 \\
67 \cdot 8 \\
61 \cdot 2 \\
73 \cdot 5\end{array}$ & $\begin{array}{l}96 \cdot 8 \\
96 \cdot 8 \\
91 \cdot 7 \\
96 \cdot 1 \\
94 \cdot 7\end{array}$ \\
\hline
\end{tabular}


laboratories who have cheerfully undertaken extra work on these studies. The work was supported by a grant from Messrs F Hoffmann-La Roche and Co, Basel, Switzerland.

\section{References}

1 Stokes EJ. Clinical Bacteriology. 3rd ed. London: Arnold, $1968 ; 179$.
2 Grüneberg RN. Susceptibility of urinary pathogens to various antimicrobial substances; a four-year study. J Clin Pathol 1976;29:292.

Requests for reprints to: Dr RN Grüneberg, University College Hospital, Gower Street, London WC1E 6AU, UK.

\section{The August 1980 Issue}

\section{THE AUGUST 1980 ISSUE CONTAINS THE FOLLOWING PAPERS}

Examination of the larynx in the histopathology laboratory L MICHAELS AND RT GREGOR

Precancerous conditions and epithelial dysplasia in the stomach BC MORSON, LH SOBIN, E GRUNDMANN, A JOHANSEN, T NAGAYO, AND A SERCK-HANSSEN

Gonadal infiltration in children with leukaemia and lymphoma H REID AND HB MARSDEN

Marrow hypoplasia with splenomegaly in adolescence JH ROBERTSON, P BURNSIDE, AND DEIRDRE C SALMON

Complement fixing antibody responses to virus infection in children with acute lymphoblastic leukaemia AW CRAFT, MM REID, J MCQUILLIN, AND PS GARDNER

Human pulmonary macrophages: relationship of smoking to presence of sea blue granules and surfactant turnover PN PLOWMAN AND RJ FLEMANS

Data processing in microbiology: an integrated, simplified system GL RIDGWAY, J BATCHEL AUDREY LUTON, AND M BARNICOAT

Distribution of pathogenic yeasts and humoral antibodies to candida among hospital inpatients FC ODDS AND EGV EVANS

A new neutrophil candida killing test: chromium-51 release from Candida guilliermondii S MARTIN, ATM GHONEIM, AND JA CHILD

Serotyping of Campylobacter jejuni/coli JD ABBOTT, BAS DALE, JOAN ELDRIDGE, DM JONES, AND ENID M SUTCLIFFE
Serological response to Campylobacter jejuni/coli infection DM JONES, JOAN ELDRIDGE, AND BAS DALE

A new selective medium for Streptococcus pneumoniae T NICHOLS AND R FREEMAN

Excretion of faecal viruses during the first year of life JEAN HARBOUR, AP SHIPP, DK WALLER, AND PG HIGGINS

Clinical applications of immunofixation: a more sensitive technique for the detection of Bence Jones protein JT WHICHER, L HAWKINS, AND J HIGGINSON

Clinical applications of immunofixation: detection and quantitation of complement activation JT WHICHER, J HIGGINSON, PG RICHES, AND S RADFORD

Human $\alpha_{1}$-microglobulin levels in various body fluids $K$ TAKAGI, $K$ KIN, Y ITOH, H ENOMOTO, AND T KAWAI

Comparison of various assays for detection of AFP in differentiating patients with primary hepatocellular carcinoma from controls SH CHAN, SH HENG, SL YO, AND CJ OON

\section{Technical method}

A modified Sandiford's counter stain for smears of blood culture MD WILLIAMS AND A BORNEMISZA

Letters to the Editors

Book reviews

Notices

Copies are still available and may be obtained from the PUBLISHING MANAGER, BRITISH MEDICAL ASSOCIATION, TAVISTOCK SQUARE, LONDON WC1H 9JR, price $£ 3.00$, including postage 